\title{
NATURAL ENVIRONMENT, STRESS AND MENTAL HEALTH
}

\author{
UDC 502.1:159.9:613.86
}

\author{
Miodrag Milenović ${ }^{1}$, Snežana Živković ${ }^{2}$, Milan Veljković \\ ${ }^{1}$ Faculty of Philosophy in Niš, University of Niš \\ ${ }^{2}$ Faculty of Occupational Safety in Niš, University of Niš
}

\begin{abstract}
In this paper, we discuss how natural environment affects mental health and how urban environment impacts on stress levels. The first part of the paper clarifies terminology used in discussing mental health, natural environment and the relationship between humans and natural environment. The second part deals with basic mechanisms of the impact of natural environment on mental health; it also discusses studies of the positive impact of nature on mental health. The third part presents Forest Therapy (Shinrin-yoku) and discusses how urban life contributes to high levels of stress. The paper suggests that being surrounded by nature can improve health. Even short-term exposure of senses is beneficial for mental health. Nature improves general mood, mental abilities and increases body vitality. The effects of green areas are particularly important because their natural vibrations benefit human natural vibrations. It has been shown that 'imitating' nature by creating visuals and emulating nature's scents or sounds can improve human psycho-physical health and the quality of life.
\end{abstract}

Key words: nature, mental health, stress, greenery, vibrations

\section{INTRODUCTION}

The idea that natural environment can affect health goes back to Hippocrates's theory of air and water as elements of the world and the surrounding environment [14]. The $19^{\text {th }}$ century American landscape architect, Frederick Law Olmsted, noted that an image of a landscape promotes relaxation and relieves tension caused by stress and noises of the urban environment [1]. At the Annual General Meeting of the British Medical Association in 1914, biologist Sir John Arthur Thomson said that modern life and technology were destroying man's evolutionary connection to natural environment [43].

The idea that contact with nature can improve health has become very popular in modern times. People not only believe that natural environment has a positive effect on

Received November 20, 2017 / Accepted January 10, 2018

Corresponding author: Snežana Živković

Faculty of Occupational Safety, Čarnojevića 10a, 18000 Niš, Serbia

E-mail: snezana.zivkovic@ znrfak.ni.ac.rs 
health, but they are trying to put those beliefs into practice too. This idea had been intuitively accepted as true for a long time, to the extent that people did not even feel the need to officially study natural environment's positive effects on health and wellbeing. However, there has been an increasing interest in studying the link between natural environment and health, where ecological psychology has played a significant role; ecological psychology collects empirical evidence which shows direct relationship between natural environment and mental health and possible underlying mechanisms.

\section{TERMINOLOGY EXPLAINED}

Mental health is not only the absence of mental disorders. World Health Organization - WHO says that "mental health is defined as a state of well-being in which every individual realizes his or her own potential, can cope with the normal stresses of life, can work productively and fruitfully, and is able to make a contribution to her or his community" [51]. The meaning of mental health is stressed in WHO definition of health as contained in its constitution: "Health is a state of complete physical, mental and social well-being and not merely the absence of disease or infirmity." Mental health is an integral part of this definition. It is a foundation for wellbeing and successful functioning not only for an individual member but for the whole community. As such, it is universal.

Ecological psychology uses the term "nature" mainly to describe a wide range of natural environments and their characteristics. As visuals, or perceptions, play an important role in man's interaction with nature, the meaning of "nature" was extended to include virtual images of nature, e.g. photos, films, etc. The term "natural environment" also has a wide definition, and includes any environment, area or place dominated by vegetation and other natural elements. Natural environments are those that have not been significantly changed or disturbed by human activities [16]. These environments usually have abundant vegetation and fauna, with a wide variety of trees, shrubs, rocks, soil, sand and water.

Urban environments are different from natural ones, having been entirely projected and built by humans. Urban environments can also have green areas, gardens, parks, forests and beaches. The terms used depend on the degree of cultivation and the size of the area. For instance, term "landscape" is mainly used to describe spaces, usually but not exclusively in the countryside, which are the result of an interaction between humans and natural factors. Term "natural area" is used to describe larger natural habitats and landscapes created naturally. And last, "green spaces" is a term mainly used to describe nature found in urban environments, such as parks, tree lines and gardens. Green space indicators are measures for the presence, quantity and quality of green spaces in a place or locality. Green space indicators can be objective and subjective. Objective indicators show percentage of vegetation or water covering a certain area, which can be calculated using maps, photography or databases of land usage, or by systematic observations in situ. Subjective indicators, on the other hand, reflect personal opinions of individuals on the quality and spread of green spaces in the area where they live.

\section{How Nature AfFects Mental HeAlth}

Positive effects of natural environment on mental health can be explained using Stress Recovery Theory [45], and Attention Restoration Theory [18]. These theories are 
complimentary because they focus on different aspects of the recovery process. The first theory is based on the premise that a person is stressed when they are facing what they perceive as dangerous or harmful. The second concentrates on recovery from fatigue caused by concentrated attention, which comes after a prolonged period of performing tasks that require a high degree of concentration and are mentally exhausting.

\subsection{Stress Recovery Theory (SRT)}

Rodger Urlich set the foundations for SRT (Stress Reduction Theory) in his paper "Aesthetic and Affective Response to Natural Environment" [45]. The basis of his theory is that the first human reaction to natural environment is unconscious and is also generalized, i.e. "black or white": we either like it or we don't.

Initial positive affective reactions happen when certain characteristics or certain preferences of the environment are present. The characteristics include the presence of natural contents, e.g. vegetation, trees, plants; structural characteristics, such as the complexity of the area; features such as symmetry, depth, the sequence of tree lines, leveled surface, the show of different elements (e.g. the curved line of the road in the distance) and the absence of danger.

Positive affective reactions to these characteristics trigger the recovery process because they provide relief from stress, which in turn reduces the level of anxiety and negative feelings, such as fear. If the image of natural environment is very attractive, the person would be even more focused on it and they would experience conscious and more powerful positive effects of nature's impact on their health.

\subsection{Attention Restoration Theory (ART)}

While SRT believes that recovery is a quick, affective process, ART (Attention Restoration Theory) emphasizes the importance of slower cognitive mechanisms of recovery. ART was first fully established by Rachel and Stephen Kaplan in their book "Experience of Nature" [18]. In this book, the Kaplans present a wide scope of their studies in humans' connection to nature, which include not only examples of recovery but also perceptions and visual preferences. In their later work, the Kaplans became famous for their "preference matrix" - a construct used to predict landscape preferences. Preference matrix is often mixed with ART, because both models have four components developed by the same authors. Still, preference matrix and ART are different models, focusing on different aspects of humans' relationship with nature.

The main premise of ART is that people have a limited ability to turn their attention to something that is not inherently interesting. Cognitive mechanism required to prevent or block the center for stimulation is called central executive mechanism. With prolonged or intensive use, this mechanism becomes used-up and becomes less and less efficient [21]. Using-up this central executive mechanism can be caused by Direct Attention Fatigue (DAF). ART assumes that stimuli from the environment can neutralize ADF when the human-environment relationship has the following characteristics:

- the ability of the environment to automatically attracts attentions, without any cognitive effort;

- the feeling of belonging or connection;

- the feeling of separation from everyday worry, engagements and woes;

- compatibility between the preferences of the individual and the characteristics of the environment. 
Natural environments are more efficient in preventing DAF then urban environments because the combination of these four characteristics defines the interaction between humans and natural environments.

\section{EVOLUTIONARY ORIGIN OF MAN'S CONNECTION TO NATURE}

Positive reactions to nature are often interpreted as the remnants of human evolution in the natural world. It is believed that certain characteristics of natural environment offered safety and survival to our ancestors. As a result, humans developed positive affective reactions to natural environment [47]. The main criticism of this theory is that humans, throughout their evolutionary development, had a tendency to settle in areas rich in vegetation and natural resources. As greenery was available to everyone, it is unclear why preferences for greenery would have [17].

\subsection{Connection with nature}

According to another new view on recovery, connection with nature begins with an observation that human life has a meaning and a purpose, when a person feels they belong to the world of nature. It is assumed that the feeling of an emotional connection with nature is an important aspect of living. During their research, Mayer et al. [30] observed positive effects of exposure to natural environment, such as developing the ability to handle life problems, which are the most common continuous causes of stress. Exposure to nature also increased perception. These findings confirm the theory that the feeling of belonging with nature contributes to its beneficial effects, whether the feeling comes from conscious or unconscious processes of perception.

\subsection{Studies in the connection between nature, stress and health}

Urlich [46] was the first to present reliable empirical evidence that exposure to nature can benefit health. In his research, he used patients' cards to follow their recovery after bladder surgery. One group of patients occupied hospital rooms with a view to natural environment, while the other was in rooms facing a neighboring building wall. Patient rooms with a view on gardens and trees had a shorter post-operative recovery period, shorter hospital stay and patients complained less about medical staff and needed lower doses of anesthetics than those who were looking at the wall. The differences in recovery speed were more prominent in the first few days after surgery, once patients became aware of their surroundings. Ulrich's findings were replicated in another study, carried out in a hospital in South Korea, where post-operative patients were placed respectively in rooms with and without pot plants [35]. His results also showed that patients in rooms with pot plants were discharged sooner, and received lower dose of anesthetic, as opposed to patients in the second group. Unlike Ulrich's patients, Korean patients were randomly placed in their respective rooms by the researchers; the rooms were almost identical except for pot plants. This ensured that the difference in recovery speed could unequivocally be assigned to the presence of pot plants. 
A large number of studies showed that therapies carried out in natural environment, such as a forest, or horticultural therapies, as well as exercising while surrounded by greenery, had beneficial effects on health [10].

Brief sensory contact with nature, e.g. looking out the window or even looking at a picture depicting nature, can also have a micro beneficial effect [20]. When these visual stimulations are repeated often over a certain period, a person can experience a feeling of increased wellness. Gulwadi studied strategies for dealing with stress in a group of in high school teachers, using stimuli from the nature [12]. Teachers who often suffered from work related stress, which was related to poor working conditions, such as overcrowded classes, preferred to spend short recesses outdoors, surrounded by nature, and enjoy brief sensory interactions with nature; it was found that bird song from the neighboring park had a particularly beneficial impact on stress reduction.

In line with these conclusions, there is increasing evidence that exposure to nature not only can be restorative, but has beneficial effects on individuals who are not stressed or fatigued $[13,19]$. Some recent studies on healthy individuals who were not stressed, showed that exposure to nature could improve general wellbeing [30] and increase vitality and energy levels [37].

In individuals from lower socioeconomic status, increasing green spaces in their environment can lower the risk of poor health. An English study showed that the death rate gap between the rich and the poor was reduced by almost $50 \%$ if the poor lived in areas abundant with greenery, as opposed to groups from the areas with no greenery [32]. Green spaces can reduce health problems caused by low socioeconomic status; it was noted that the quality of the greenery also played a role [49]. Researchers gathered reliable evidence on the quality of environment based on certain indicators. Individuals who lived in areas with high quality green spaces generally enjoyed better health in comparison to those surrounded by lower quality of greenery, regardless of the size of green spaces.

Nordh et al. [34] analyzed what would be the optimum time spent in the natural environment to feel the benefits; the results showed that it was not necessary for this period to be long. However, in other studies, they found that a longer stay had more benefits in cases when individuals were coming from urban environments with minimal green spaces.

In a study White et al. [52] conducted, they concluded that there was an upper limit to the benefits felt when exposed to certain natural elements, such as water. On the other hand, same authors found that living near "blue waters", such as oceans, the sea, lakes and big rivers, had continuous positive impact on general health and wellness [53].

Research has shown that exposure not only to real nature but also to sensory stimulations, e.g. visual clips, pictures, auditory or olfactory stimulations, can have recovery effects on psychophysical health in humans [30,48]. Tinio and Leder conducted a study using short exposure to photos $(.01 \mathrm{sec})$ of natural and urban environments [41]. Results showed higher preferences for photos depicting nature to those with built urban environments.

Studies where brain fMRI was used when pictures or nature and urban environments were being shown, established higher brain activities in areas linked to positive mental state, emotional stability, altruism, empathy and depth of love when natural environment was shown. On the other hand, scenes of urban environments continuously increased activities in amygdala and the centers for fear, negative arousal and perception of risk [23,24].

The benefits of natural environments are further confirmed by well- established connections between stress, agitation, cognitive fatigue and mental disorders such as depression and anxiety 
[31]. Build-up of stressful life events, which range from every day unpleasantness to traumatic experiences, is linked to potential mental health problems [25]. Individuals who have depression often suffer fatigue and cognitive attention deficit. Cognitive requirements may contribute to increased mental fatigue and increase the activity of sympathetic nervous system. Mental fatigue lowers the ability for emotional coagulation [11] and increases the perception of physical exertion; it may lower motivation for physical activity or can negatively impact on the use of energy during the activity [3]. Once mental fatigue sets, it prevents the ability to regulate disruptive stimuli in the environment [9]. Mental fatigue and related issues, e.g. lack of sleep, would reduce the ability to focus attention [7].

Contact with nature is positively linked to vitality, positive emotions and content, and negatively with anxiety and anger [5]. Continuous awareness, i.e. awareness of the present time and thoughts, emotions and sensations, as well as attentiveness, of the beauty of nature, is a prerequisite for attaining maximum health benefits from the natural surrounding [54]. One cannot get maximum benefits from looking at nature, or even spending time in a natural environment, unless they have some awareness and are focused on the moment.

Several studies researched how the distance between home and the natural environment impacted on mental health. Results showed that the greater the distance between home and the environment rich in green spaces, the higher individual's score was on the scale of perceived stress, and the lower on the indicators of good general health [29]; on the other hand, if an individual had a subjective perception that they lived near an environment with optimal green spaces, they led a happier life [50] and enjoyed better mental health [39].

In a Netherlands research study which included more than 10,000 subjects, De Vries et al. [6] found that the individuals who lived in an environment with high percentage of green spaces within 1 to $3 \mathrm{~km}$, had better mental health and less complaints about their health as opposed to those who had less green space. Another Netherlands study [29] found that individuals who lived in areas poor in green spaces had a higher risk of developing depression and anxiety disorders, in comparison to those who lived in areas rich in greenery.

Some recent research studies point to a conclusion that visible degradation of environment does have negative impact on health. Changes in vegetation and loss of trees in communities and regions are linked to an increase in physical illnesses and worsening of mental health. It seems that these losses may directly cause depressions symptoms [8].

One of the explanations for nature's positive impact on people, forests in particular, is based on its vibrations, the frequencies of which are beneficent for humans. Hans Jenny was first to discuss this in his book "Cymatics"; a term he coined to describe the effects of vibrations on matter. Jenny [15] carried out numerous experiments to prove that vibrations could restructure shapes and samples of matter. Much later, Silverstone demonstrated that natural environment can increase vibrations in humans to frequencies which would, on a psychological level, manifest as positive emotions, e.g. love at $147 \mathrm{~Hz}$ or happiness at $205 \mathrm{~Hz}[38]$.

\subsection{Forest Therapy (Shinrin-yoku)}

The concept of Forest therapy or shinrin-yoku, was first introduced in Japan in 1982; the term means "taking in the forest atmosphere" or "forest bathing". Park et al. [36] showed that a two hour walk in the forest improves body immunity and blood pressure, calms the mind and improves its clarity. In addition, the forest can improve all senses, especially 
hearing and smell [33]. Tsunetsugu et al. [44] concluded that walking for 40 minutes in a cedar forest will bring about relaxation, better frame of mind and an increase in energy. Toa et al. [42] found that as little as 20 minutes of forest therapy will have beneficial impact on blood circulation in the brain and improves relaxation. This therapy also lowers levels of stress hormones, in particular adrenalin and cortisol, which in turn strengthens the immunity system.

Tokyo University Medical School researchers found that a day trip to the forest, or just a few hours each day over three days, will have a far more beneficial impact on the immunity system than walking in the city for the same length of time [40]. It has been shown that psychotherapeutic sessions, such as cognitive-behavioral therapy, produce better results when carried out in the forest instead of an urban office [22].

\subsection{Urban life and stress}

Urban environments are attractive because they offer many stimuli, more job opportunities as well as opportunities for professional development and entertainment. However, urban environment can cause negative stress, as a result of traffic noise, air pollution, high average temperature and high population density. These stressors can have various physical and mental consequences, including health problems and poor mental functioning.

Urban environment can cause stress when an individual is aware of the imbalance between the requirement of the environment and their personal needs. Whether this situation will be seen as stressful, irritating or upsetting will depend on how serious and predictable a threatening situation is and whether the individual feels that they are in control [27].

In an urban surrounding, a simultaneous presence of multiple stressors can lead to overstimulation [2]. According to these theories, handling numerous stressors requires continuous cognitive efforts. With time, prolonged efforts will lead to mental fatigue and cognitive functioning will suffer as a result. To compensate for reduced abilities, people are forced to apply adequate strategies. Most common reaction to overstimulation is the so called "tunnel vision", when the individual is focused only on the immediate task, at the expense of everything else. When attention is reduced to a narrow task because of stress or overloading, we feel that we cannot afford to "waste" even the smallest amount of energy on "peripheral" things such as "small talk" with a neighbor. For this reason, the demands of urban life can negatively impact on social interactions, where the individual loses community support, which causes them to become socially isolated.

However, urban environments, with the right architecture and landscape adapted to human needs, do not have to cause stress and illness. Green spaces, such as parks and gardens, will improve health and wellbeing of urban population in many ways, including providing a sense of security [28].

Urban environments can enable psychological restoration, and reduce stress and mental fatigue [18]. For example, a research study carried out in a poor suburb of Chicago, where housing commission type buildings and apartments were of similar design but had different sizes of green spaces, showed that individuals who lived in buildings with no greenery, were more likely to exhibit aggressiveness and family violence than those who were surrounded by greenery [26]. These high levels of aggressive behaviors were explained by lower levels of awareness. Interestingly, it was shown that professional truck drivers report lower stress levels when driving in natural than in urban environments [4]. 


\section{CONCULSION}

Fast life often means that we forget to pay attention to our environment and the nature. It is a fact, however, that life is simply not possible without nature. Numerous studies show that natural environment has a positive impact on mental health; it benefits recovery from stress and lowers mental fatigue. Two leading theories, known as SRT and ART, both talk about restorative effects of the nature. While empirical evidence for nature's restorative effects on humans is becoming more accepted and applied in the health sector, architecture and landscaping, further research is necessary to explore natures' positive impact on mental health.

Acknowledgement: The research presented in this paper was financed by the Ministry of Science and Technological Development of Serbia within the projects III 43014 and III 42006.

\section{REFERENCES}

1. Beveridge, C.E. (1977). Frederick Law Olmsted's Theory of Landscape Design, Nineteenth Century, 3, pp. 38-43.

2. Broadbent, D.E. (1958). Perception and Communication, London: Pergamont Press.

3. Brownsberger, J., Edwards, A., Crowther, R., Cottrell, D. (2013). Impact of mental fatigue on self-paced exercise. International Journal of Sports Medicine, 34, pp. 1029-1036.

4. Cackowski, J.M., Nasar, J.L. (2003). The restorative effects of roadside vegetation: Implications for automobile driver anger and frustration. Environment and Behavior, 35(6), pp. 736-751.

5. Capaldi, C.A., Dopko, R.L., Zelenski, J.M. (2014). The relationship between nature connectedness and happiness: a meta-analysis. Frontiers in Psychology, 5, pp. 976-981.

6. De Vries, S., Verheij, R.A., Groenewegen, P.P., Spreeuwenberg, P. (2003). Natural environments healthy environments? An exploratory analysis of the relationship between greenspace and health. Environment and Planning, 35(10), pp. 1717-1731.

7. Diener, E., Kanazawa, S., Suh, E.M., Oishi, S. (2014). Why people are in a generally goodmood. Personality and Social Psychology Review, 19(3), pp. 235-256.

8. Donovan, G.H., Butry, D.T., Michael, Y.L., Prestemon, J.P., Liebhold, A.M., Gatziolis, D., Mao, M.Y. (2013). The relationship between trees and human health: evidence from the spread of the emerald ash borer. American Journal of Preventive Medicine, 44, pp. 139-145.

9. Faber, L.G., Maurits, N.M., Lorist, M.M. (2012). Mental fatigue affects visual selective attention. PLoS ONE, 7: e48073.

10. Frumkin, H. (2001). Beyond toxicity: Human health and the natural environment. American Journal of Preventive Medicine, 20(3), pp. 234-240.

11. Grillon, C., Quispe-Escudero, D., Mathur, A., Ernst, M. (2015). Mental fatigue impairs emotion regulation. Emotion, 15 (3), pp. 383-389.

12. Gulwadi, G.B. (2006). Seeking restorative experiences: elementary school teacher's choices for places that enable coping with stress. Environment and Behavior, 38(4), pp. 503-520.

13. Hartig, T. (2007). Three steps to understanding restorative environments as health resources. In Thompson C. \& Travlou, P. (Eds.), Open space: People space (pp. 163-179). London: Taylor \& Francis.

14. Hippocrates (2007). On Airs, Waters and Places, Adelaide: University of Adelaide.

15. Jenny, H. (2001). Cymatics: A Study of Wave Phenomena \& Vibration, Berkeley-CA: MACROmedia.

16. Johnson, D.L., Ambrose, S.H., Bassett, T.J., Bowen, M.L., Cummey, D.E., Isaacson, J.S., Johnson, D.N., Lamb, P., Saul, M., Winter-Nelson, A. (1997). Meanings of environmental terms. Journal of Environmental Quality, 26, pp. 581-589.

17. Joye, Y., Van den Berg, A.E. (2011). Is love for green in our genes? A critical analysis of evolutionary assumptions in restorative environments research. Urban Forestry \& Urban Greening, 10(4), pp. 261-268.

18. Kaplan, R., Kaplan, S. (1989). The experience of nature: A psychological perspective. New York: Cambridge University Press. 
19. Kaplan, S. (1995). The restorative benefits of nature: Toward an integrative framework, Journal of Environmental Psychology, 15(3), pp. 169-182.

20. Kaplan, R. (2001). The nature of the view from home - psychological benefits. Environment and Behavior, 33(4), pp. 507-542.

21. Kaplan, S., Berman, M.G. (2010). Directed attention as a common resource for executive functioning and self-regulation. Perspectives on Psychological Science, 5(1), pp. 43-57.

22. Kim, W., Lim, S.K., Chung, E.J., Woo, J.M. (2009). The effect of cognitive behavior therapy based psychotherapy applied in a forest environment on physiological changes and remission of major depressive disorder. Psychiatry Investigation, 6, pp. 245-254.

23. Kim, T.H., Jeong, G.W., Baek, H.S., Kim, G.W., Sundaram, T., Kang, H.K., Lee, S.W., Kim, H.J., Song, J.K. (2010). Human brain activation in response to visual stimulation and rural urban scenery pictures: a functional magnetic resonance imaging study. The Science of Total Environment, 408, pp. 2600-2607.

24. Kim, G.W., Song, J.K., Jeong, G.W. (2011). Neuro-anatomical evaluation of human suitability for rural and urban environment by using fMRI. Korean Journal of Medical Physics, 22, pp. 18-27.

25. King, K., Ogle, C. (2014). Negative Life Events Vary by Neighborhood and Mediate the Relation between Neighborhood Context and Psychological Well-Being. PLOS ONE 9(4): e93539.

26. Kuo, F.E., Sullivan, W.C. (2001). Aggression and violence in the inner city: Effects of environment via mental fatigue. Environment and Behavior, 33(4), pp. 543-571.

27. Lazarus, R.S., Cohen, J.B. (1977). Environmental stress. In Altman, I. and Wohl-will, J.Y. (Eds.) Human Behavior and Environment, Vol. 2, pp. 89-128, New York: Plenum Press.

28. Maas, J., Verheij, R.A., de Vries, S., Spreeuwenberg, P., Schellevis, F.G., Groenewegen, P.P. (2009). Morbidity is related to a green living environment. Journal of Epidemiolgical Community Health, 63, pp. 967-973.

29. Maas, J., Verheij, R.A., Groenewegen, P.P., de Vries, S., Spreeuwenberg, P. (2006). Green space, urbanity, and health: how strong is the relation? Journal of Epidemiological Community Health, 7, pp. 587-592.

30. Mayer, F.S., Frantz, C.M., Bruehlman-Senecal, E., Dolliver, K. (2009). Why is nature beneficial? Environment and Behavior, pp. 607-643.

31. Mechakra-Tahiri, S., Dubé, M., Zunzunegui, M.V., Préville, M., Berbiche, D., Brassard, J. (2013). Pattern of change of depressive disorder over a one-year period among community-dwelling older adults in Québec, Depression Research and Treatment, article ID 451708, doi:10.1155/2013/451708.

32. Mitchell, R., Popham, F. (2008). Effect of exposure to natural environment on health inequalities: An observational population study. Lancet, 372 (9650), pp. 1655-1660.

33. Mishima, R., Tsunetsugu, Y., Miyazaki,Y., Yamamura, C., Yamada,Y. (2004). Effects of sounds generated by a dental turbine and stream on regional cerebral blood flow and cardiovascular responses. Odontology, 92(1), pp. 54-60.

34. Nordh, H., Hartig, T., Hägerhäll, C.M., Fry, G. (2009).Components of small urban parks that predict the possibility for restoration. Urban Forestry \& Urban Greening, 8(4), pp. 225-235

35. Park, S.H. (2006). Randomized clinical trials evaluating therapeutic influences of ornamental indoor plants in hospital rooms on health outcomes of patients recovering from surgery. Unpublished Dissertation, Kansas: Kansas State University.

36. Park, B.J., Tsunetsugu, Y., Kasetani, T., Kagawa, T., Miyazaki, Y. (2010). The physiological effects of shinrin-yoku (taking in the forest atmosphere or forest bathing): evidence from field experiments in 24 forests across Japan. Environmental Health Preventive Medicine, 15, pp. 18-26.

37. Ryan, R.M., Weinstein, N., Bernstein, J., Brown, K.W., Mistretta, L., Gagne, M. (2010).Vitalizing effects of being outdoors and in nature. Journal of Environmental Psychology, 30(2), pp. 159-168.

38. Silverstone, M. (2011). Blinded by Science, London: Lloyd's Wold Publishing.

39. Sugiyama, T., Leslie, E., Giles-Corti, B., Owen, N. (2008). Associations of neighbourhood greenness with physical and mental health: do walking, social coherence and local social interaction explain the relationships? Journal of Epidemiological Community Health, 62, e9.

40. Takayama, N., Korpela, K., Lee, J., Morikawa, T., Tsunetsugu, Y., Park, B.J., Li, Q., Tyrväinen, L., Miyazaki, Y., Kagawa, T. (2014). Emotional, restorative and vitalizing effects of forest and urban environments at four sites in Japan. International Journal of Environmental Research and Public Health, 11, pp. 7207-7230.

41. Tinio, P.P.L., Leder, H. (2009). Natural scenes are indeed preferred, but image quality might have the last word. Psychology of Aesthetics,Creativity, and the Arts, 3(1), pp. 52-56.

42. Toa, M., Den, R., Hasegawa-Ohira, M., Morimoto, K. (2013). Effects of woodland walking on salivary stress markers cortisol and chromogranin. Complementary Therapies and Medicine, 21, pp. 29-34. 
43. Tomson, J.A. (1934). Biology for Everyman, Vol.1, London: J.M. Dent\&Sons.

44. Tsunetsugu, Y., Park, B.J., Miyazaki, Y. (2010). Trends in research related to "Shinrin-yoku" (taking in the forest atmosphere or forest bathing) in Japan. Environmental Health Preventive Medicine, 15, pp. 27-37.

45. Ulrich, R.S. (1983). Response to Natural. Behavior and the Natural Environment, 6, 85.

46. Ulrich, R.S. (1984). View through a window may influence recovery from surgery. Science, 224 (4647), pp. 420-421.

47. Ulrich, R.S. (1999). Effects of gardens on health outcomes: Theory and research. In Cooper-Marcus, C. \& Barnes, M. (Eds.), Healing gardens: Therapeutic benefits and design recommendations, pp. 27-86. New York: John Wiley.

48. Ulrich, R.S., Simons, R.F., Miles, M.A. (2003). Effects of environmental simulations and television on blood donor stress. Journal of Architectural and Planning Research, 20(1), pp. 38-47.

49. Van Dillen, S.M.E., De Vries, S., Groenewegen, P. P., Spreeuwenberg, P. (2011). Greenspace in urban neighbourhoods and residents' health: Adding quality to quantity. Journal of Epidemiology and Community Health, 66 (6), e8.

50. Vemuri, A.W., Grove. M.J., Wilson, M.A., Burch, W.R. (2011). A tale of two scales: evaluating the relationship among life satisfaction, social capital, income, and the natural environment at the individual and neighborhood levels in metropolitan Baltimore. Environmentak Behavavior, 43, pp. 3-25.

51. WHO, (2014). Mental health: a state of well-being, http://www.who.int

52. White, M., Smith, A., Humphreyes, K., Pahl, S., Snelling, D., Depledge, M. (2010). Blue space: The importance of water for preference, affect, and restorativeness ratings of natural and built scenes. Journal of Environmental Psychology, 30(4), pp. 482-493.

53. White, M.P., Alcock, I., Wheeler, B.W., Depledge, M.H. (2013). Coastal proximity, health and wellbeing: results from a longitudinal panel survey. Health \& Place, 23, pp. 97-103.

54. Zhang, J.W., Howell, R.T., Iyerb, R. (2014). Engagement with natural beauty moderates the positive relation between connectedness with nature and psychological well-being. Journal of Environmental Psychology, 38, pp. 55-63.

\section{PRIRODNO OKRUŽENJE, STRES I MENTALNO ZDRAVLJE}

U ovom radu govorimo o tome kako prirodno okruženje utiče na mentalno zdravlje i kako urbana sredina utiče na nivo stresa. Prvi deo rada pojašnjava terminologiju koja se koristi u razmatranju mentalnog zdravlja, prirodnog okruženja i odnosa između ljudi i prirodnog okruženja. Drugi deo se bavi osnovnim mehanizmima uticaja prirodnog okruženja na mentalno zdravlje; takođe razmatraju se studije o pozitivnom uticaju prirode na mentalno $z$ dravlje. Treći deo predstavlja Forest Therapy (Shinrin-yoku) i razmatra kako urbani život doprinosi visokim nivoima stresa. U radu ukazuje da okruženje prirodom može poboljšati zdravlje. Čak i kratkotrajno izlaganje čula korisno je za mentalno zdravlje. Priroda poboljšava opšte raspoloženje, mentalne sposobnosti i povećava telesnu vitalnost. Efekti zelenih površina su posebno važni jer njihove prirodne vibracije koriste ljudskim prirodnim vibracijama. Dokazano je da ,,imitiranje“ prirode stvaranjem vizuelnih $i$ oponošanje prirodnih mirisa $i$ zvukova može poboljšati ljudsko psiho-fizičko zdravlje i kvalitet života.

Ključne reči: priroda, mentalno zdravlje, stres, zelenilo, vibracije 